\title{
Analysis of Live Goats Market Chain: The Case of Pastoralists in Moyale District, Ethiopia
}

\author{
Umer Abdinasir \\ Department of Agricultural Economics, College of Agriculture, \\ Woldia University, Woldia, Ethiopia \\ Jema Haji \\ School of Agricultural Economics, and Agribusiness and Value Chain Management, \\ Haramaya University, Haramaya, Ethiopia \\ Bosena Tegegne \\ Department of Agricultural Economics, College of Agriculture and Natural Resources, \\ Bahir Dar University, Bahir Dar, Ethiopia
}

\begin{abstract}
Goat production and marketing provide vast socio-economic benefits. However, the subsector has encountered with lack of information about what determines goat market participation, supply, and outlet choice. Therefore, the study was intended to analyze the live goat market chain in the Moyale district. Both primary and secondary data were used. Primary data were collected from a randomly selected sample of 196 goat producers and were analyzed using econometric methods. To investigate the determinants of household market participation and supply, Heckman's two-stage procedure was used. Heckman's $1^{\text {st }}$ stage result showed that different variables have affected live goats' market participation decisions either positively and negatively. Heckman's $2^{\text {nd }}$ stage result indicated that the number of live goats supplied to the market is also affected either positively or negatively by different variables. To identify factors affecting outlet choice multivariate probit model was used. Multivariate probit model results showed that distance to market and selling price significantly affected the entire outlets (namely; large scale traders, small-scale traders, cooperatives, collectors, and consumers) either positively or negatively. The study recommended the need to develop market infrastructures, improve the capacity of productive labor, promote credit institutions, and provision of awareness creation training towards goat trading business.
\end{abstract}

Keywords: Heckman two stages, Live Goats, Market outlet choice, Market participation, Multivariate probit model

DOI: $10.7176 / \mathrm{JMCR} / 79-01$

Publication date:May $31^{\text {st }} 2021$

\section{INTRODUCTION}

Ethiopia has the highest number of livestock in Africa. There is about 30.2 million, 8.13 million and 868,571 goats population in Ethiopia, Oromia region and Borena zone respectively (CSA, 2017). The total number of goat in Moyale district was projected to be 58,792 (MDPDO, 2017). The livestock sub-sector contributes $42 \%$ of agricultural GDP, about $16 \%$ of total GDP and $62 \%$ of the household income on average (Birara and Zemen, 2016). Goats were considered as most important livestock species, and are capable of surviving, reproducing, providing milk, meat, and generating income to smallholder farmers (Gebreyowhens and Kumar, 2018). Goat production provides a lot of socio-economic benefits which improves the livelihoods of communities. Regular cash income from selling of goats was the most important reason for keeping goats, followed by other tangible and intangible benefits (Charles et al., 2015).

Even though the goat meat demand has generally increased in the local and foreign markets, the supply of goat to both markets is not well strategized as production is not market-oriented (Legese et al., 2014). Despite the wonderful benefit goats provide in the living condition of rural producers, the sub-sector has remained unconsidered in the case of research particularly in marketing aspect (Solomon et al., 2014). Moyale market delivers live goats to central market (Ethiopia) and to Nairobi markets. Information about the potential goat buyers in the district is unknown and the way the pastoralists choose the outlets is not clear. This information gap continues to hamper competence of live goat market in the district.

To cover these breaches and develop a workable guide on marketing of live goats for the pastoral community that rears large proportion of goats, undertaking research on goat market participation, supply and outlet choice is believed to enhance marketing by providing updated information and portrayal of goat market in the study area. This ensures a complete understanding of what determines goat market participation; supply and outlet choice with a view of suggesting possible policy recommendations aimed at empowering goat producers and other market chain participants to gain from marketing. The study objectives are: (1) to analyze the 
determinants of live goat's market participation and supply; and (2) to identify live goats' market outlets and factors affecting their choices.

\section{RESEARCH METODOLOGY}

\subsection{Descriptions of the Study Area}

Borena zone encompass thirteen districts of which one is Moyale district. Moyale district is found about $770 \mathrm{~km}$ south of Addis Ababa. The districts area coverage is about $14,810 \mathrm{~km}^{2}$ and it is divided into 19 kebeles, two of which are in Moyale Town (Desta et al., 2008). Moyale Town includes two countries (Ethiopia and Kenya) and two of Ethiopia's regions (Oromia and Somali). It is a busy market for the informal and formal trade of food commodities and livestock (FAO, 2013). The total number of livestock in Borena zone was projected as 1,056,040 cattle, 573,369 sheep, 868,571 goats and 51,607 camels (CSA, 2017). The livestock population of Moyale district was estimated to be 48,863 cattle, 58,792 goat, 13,861 sheep, 14,540 camel, 4,725 donkey, 14 mule and 14,446 poultry (MDPDO, 2017).

\subsection{Data Types, Sources and Methods of Collection}

The study employed both primary and secondary data. Secondary data were gathered from different records of district office of agriculture, CSA, web sites and other published and unpublished relevant sources. Primary data were gathered using structured questionnaire. The questionnaire were pre-tested and amended based on feedbacks from the pre-test. Personal observations and group discussions with community members were also done for triangulation. Trained enumerators were hired to gather data under the supervision of the principal researcher.

\subsection{Sampling Technique and Sample Size}

Goats producing kebeles and sample households were selected by utilizing a two-stage sampling procedure. From 19 kebeles in the district 10 goat producing kebeles were purposively selected.

At the first stage, three representative kebeles namely Kabanawa, Mado Migo and Chamuk were selected randomly from selected 10 goat producing kebeles. In the second stage, from three randomly selected kebeles, 196 sample households head were selected randomly based on the probability proportional to size. Sample size of goat producers were determined by using Cochran (1977) formula which is developed to calculate a representative sample for proportions by considering the $95 \%$ confidence level and $7 \%$ level of precision. The formula is:

$$
n=z^{2} p q / e^{2}
$$

Where, ' $n$ ' is the sample size of goat producer households ' $z$ ' is the selected critical value of desired confidence level $(z=1.96)$ and $\mathrm{e}$ is the desired level of precision $(e=0.07), \mathrm{p}$ is the expected proportion of market participants from population of the goat producers $(p=0.5)$ and $q=p-1=0.5$. Hence, the sample size is:

$$
n=\frac{1.96^{2} \times 0.5(0.5)}{0.07^{2}}=196
$$

The distribution of goat producers and sample households are given in the table 1.

Table 1: Sample size distribution for each sample kebeles

\begin{tabular}{lll}
\hline Name of kebeles & Number of goat producing household & Number of sample household \\
\hline Chamuk & 6,776 & 45 \\
Kabanawa & 14,017 & 94 \\
Mado Migo & 8509 & 57 \\
\hline Total & 29,305 & 196
\end{tabular}

Source: Own computation based on kebele administration data, 2017

\subsection{Methods of Data Analysis}

\subsubsection{Determinants of household's market participation and supply of live goats}

Heckman two-steps choice model was found to be applicable to investigate factors touching goat market participation decision and factors touching number of goats brought to the market at the same time since it controls selectivity bias. Specification of the Heckman two-step technique is given in terms of the probability of goat market participation (GMP), and goat market supply (GMS) is: 
The participation Equation/the binary probit equation

$$
\begin{array}{ll}
Y_{1 i}=x_{1 i} \beta_{1}+u_{1 i} & u_{1 i} \sim N(0,1) \\
G M P=1 \text { if } Y_{1 i}>0 & \\
G M P=0, \text { if } Y_{1 i} \leq 0 &
\end{array}
$$

Where $Y_{1 i}$ : The latent regressed variable that is not observed.

$x_{1 i}$ : Factors that are assumed to have effect on the chance of sampled household market participation

$\beta_{1}$ : Vector of unknown parameter in participation equation

$u_{1 i}$ : Residuals that are independently and normally distributed with zero mean and constant variance

The observation equation/the supply equation

$$
G M S=Y_{2 i}=x_{2 i} \beta_{2}+u_{2 i} \quad u_{2 i} \sim N\left(0, \delta^{2}\right)
$$

$Y_{2 i}$, is observed if and only if $G M S=1$. The variance of $u_{1 i}$ is normalized to one because only $G M S$, not $Y_{1 i}$ is observed. The error terms, $u_{1 i}$ and $u_{2 i}$, are assumed to be bivariate, normally distributed with correlation coefficient. $\beta_{1}$ and $\beta_{2}$ are the parameter vectors. By employing ordinary least squares method $Y_{2 i}$, is regressed on the independent variables $x_{1 i}$, and the vector of inverse Mills ratios $\left(\lambda_{i}\right)$ from the selection equation. Where:

$Y_{2 i}$ : The observed regressand variable

$x_{2 i}$ : Factors expected to affect number of goat supplied

$\beta_{2}$ : Vector of unidentified parameter in the supply equation

$u_{2 i}$ : Residuals in the supply equation that are independently and normally distributed with zero mean and constant variance.

$$
\lambda_{i}=\frac{f(x \beta)}{1-F(x \beta)}
$$

$f(x \beta)$ is density function and $1-F(x \beta)$ is distribution function

\subsubsection{Goats' market outlets and factors affecting outlets choice}

Multivariate probit model was found to be appropriate to analyze factors affecting goat producers' market outlets choice decisions since it capture the influence of the set of explanatory variables on each of the five outlet choices in the study area, while error terms are allowed to be freely correlated.

The observed outcome of choosing market outlets of live goats can be modeled following random utility formulation for individual choice (Greene, 2012). Assume the $i^{\text {th }}$ live goat supplier household $(i=1,2 \ldots \ldots . N)$, encountering with a problem to decide on whether to choose existing market outlets or not. Let $\mathrm{U}_{0}$ represent the benefits to the goat producing households who chooses large scale traders, and let $\mathrm{U}_{\mathrm{k}}$, be the advantage of goat producing household to select the $\mathrm{K}^{\text {th }}$, live goat market outlet: As $\mathrm{K}$ symbolizes choice of large scale traders (Y1), small scale traders (Y2), cooperatives (Y3) collectors (Y4) and consumers (Y5). If $Y *_{i k}=U *_{k}-U_{0}>0$, the goat supplier household decides to select the $\mathrm{K}^{\text {th }}$ market outlets. The latent variable is the net earnings $\left(Y *_{i k}\right)$ which the goat supplier household gains from choosing a market outlets is determined by witnessed independent factors (Xi) and the error terms $\left(\varepsilon_{i}\right)$ :

$$
Y *_{i k}=X_{i} \beta_{k} \varepsilon_{i} \quad\left(k=Y_{1}, Y_{2}, Y_{3}, Y_{4}, Y_{5}\right)
$$

Using the indicator function, the unobserved preferences in equation (9) translates into the observed binary outcome equation for each choice as follows: 


$$
Y_{i k}=\left\{\begin{array}{l}
1 \text { if } Y_{i k}^{*}>0 \\
0 \text { otherwise }
\end{array} \quad\left(K=Y_{1}, Y_{2}, Y_{3}, Y_{4}, Y_{5}\right)\right.
$$

In multivariate model, where the choice of several market outlets is possible, the error terms jointly follow a multivariate normal distribution (MVN) with zero conditional mean and variance normalized to unity (for identification of the parameters) where $\left(\mu_{y 1}, \mu_{y 2}, \mu_{y 3}, \mu_{y 4}\right) \sim M V N(0, \Omega)$ and the symmetric covariance matrix $\Omega$ is given by:-

$\Omega=\left[\begin{array}{cccc}1 & \rho_{y 1 y 2} & \rho_{y 1 y 3} & \rho_{y 1 y 4} \\ \rho_{y 2 y 1} & 1 & \rho_{y 2 y 3} & \rho_{y 2 y 4} \\ \rho_{y 3 y 1} & \rho_{y 3 y 2} & 1 & \rho_{y 3 y 4} \\ \rho_{y 4 y 1} & \rho_{y 4 y 2} & \rho_{y 4 y 3} & 1\end{array}\right]$

Off-diagonal elements crossing the covariance matrix are of particular interest, it denotes unnoticed association among the stochastic components of various types of outlets. This supposition is that equation (11) makes a MVP model which jointly signifies decision to select specific goat market outlets. The specification using off-diagonal elements which are non-zero, permits for association across error terms of numerous latent equations, that denotes unobserved features that influence the choice of different live goat market outlets. Following the form applied by Cappellarri and Jenkins (2003), the log-likelihood function correlated with a sample outcome is provided by:

$$
\ln L=\sum_{i=1}^{N} \omega_{i} \ln \Phi\left(\mu_{i}, \Omega\right)
$$

Where $\omega_{i}$ is an optional weight for observation $\mathrm{i}$, and $\Phi$ is the multivariate standard normal distribution with arguments $\mu_{i}$ and $\Omega$, where $\mu_{i}$ can be denoted as:-

$$
\begin{aligned}
& \mu=\left(k_{i 1} \beta_{1} X_{i 1}, k_{i 2} \beta_{2} X_{i 2}, k_{i 3} \beta_{3} X_{i 3}\right), \text { While } \Omega_{i k}=1 \text { for } j=k \text { and } \\
& \Omega_{j k}=\Omega_{k j}=k_{i j} k_{i k} \rho_{j k} \text { for } j \neq k, k=1,2,3 \ldots \text { with } k_{i k}=2 y_{i k}-1
\end{aligned}
$$

\section{RESULTS AND DISCUSSION}

\subsection{Determinants of Live Goats Market Participation and Supply}

\subsubsection{Determinants of Live Goats Market Participation Decision (Hechman $1^{\text {st }}$ step)}

Among hypothesized twelve explanatory variables, five of them were identified to significantly influenced goat market participation decision. Among hypothesized independent variables family size, credit use and lagged price affected the goat market participation decision positively and significantly. Whereas distance to the nearest livestock market and other income from off/non-goat activities reduces live goat market participation decision (Table 2).

Family size (manequi): This variable influenced the live goat market participation decision positively and significantly at 5\% level of significance. As households labor force increase by one man equivalent, the probability of producer household participation decision in live goat market increases by $4.6 \%$. The reason behind might be that those households who have higher family labor force can manage to drive the goat flock to the market easily and improves level of participation. The result is similar to the findings of Gezehagn (2015) who found that household size positively and significantly affected beef cattle market participation decision.

Distance to market (dismkt): This variable influenced household's goat market participation decision negatively and significantly at 5\% level of significance. As distance from the closest livestock market increase by one $\mathrm{km}$ the likelihood of the household to participate in goat market reduced by $2.09 \%$. This might be due to the far distance the household resides from the nearest livestock market; the less likely the household involved in selling live goat due to long trekking time and relatively high marketing costs. This is associated with the findings of Gebremedhin et al. (2015) and Zemeda (2016) who found that distance to nearest livestock market negatively and significantly influenced small ruminants' market participation decision.

Credit use (credit): Credit use was found to determine the probability of participation in goat markets significantly and positively at $1 \%$ probability level. As compared to credit non-users, those households with credit use participate in live goat markets by $8.7 \%$ more. The reason behind this might be that credit helps household in covering marketing costs and pave way for better market participation. This is in line with Gezehagn (2015) who found that credit access in beef cattle production rises the likelihood of producers' participation in the markets. 
Table 2: Results of Heckman first-step determinants of goat market participation decision

\begin{tabular}{lllll}
\hline Variables & Marginal effect & Std. Err. & $\mathrm{Z}$ & $\mathrm{P}>\mathrm{Z}$ \\
\hline Age of household head & 0.0017 & 0.025974 & 0.49 & 0.627 \\
Sex of household head & 0.0641 & 0.341269 & 1.18 & 0.239 \\
Education level & 0.0158 & 0.114534 & 1.05 & 0.295 \\
Family size & $0.0459 * *$ & 0.14707 & 2.38 & 0.017 \\
Distance to market & $-0.0209 * *$ & 0.074344 & -2.13 & 0.033 \\
Number of goat owned & 0.0344 & 0.185403 & 1.41 & 0.159 \\
Other livestock owned & -0.0041 & 0.027882 & -1.12 & 0.263 \\
Extension contact frequency & 0.0014 & 0.075031 & 0.14 & 0.889 \\
Credit use & $0.0873^{*}$ & 0.425632 & 1.82 & 0.069 \\
Veterinary service use & 0.0436 & 0.347096 & 0.98 & 0.329 \\
Lagged price & $0.00003 * *$ & 0.000472 & 2.18 & 0.029 \\
Off/non goat income & $-0.0002 * * *$ & $4.36 \mathrm{E}-05$ & -4.58 & 0.000 \\
Constant & - & 1.506305 & -0.29 & 0.768 \\
\hline
\end{tabular}

Note: Dependent variable is mktprt. $* * *, * *$ and $*$ are statistically significant at $1 \%, 5 \%$ and $10 \%$ significance levels respectively.

Source: Own computation from survey result, 2017

Lagged price (Igprice): The seasonal average lagged price of goat in the previous year was found to determine the probability of participation in live goat markets positively and significantly at a $5 \%$ level of significance. As lagged price for goat raises by one birr the likelihood of live goat market participation rises by $0.003 \%$. The intuition behind this might be that the relatively high market price in the previous year may reassure the households to participate in the live goat market. The study by Shambel (2013) also reported the same result.

Other incomes excluding income from goat (othrinc): This variable influenced goat market participation decision negatively and significantly at $1 \%$ significance level. The study indicated that involvement in other activities excluding goat marketing decreases the probability of participation of producers in goat marketing by $0.02 \%$. This is mainly due to the fact that, households participating in other non-goat activities are gaining the income from on/off farm activities rather than goat market, this makes the household to abstain from goat market participation and decreases pastoralists goat market participation. This result is in line with Jemal (2017) who reported the same results.

\subsubsection{Determinants of Number of Live Goats Market Supply (Heckman $2^{\text {nd }}$ step)}

The Heckman second step estimation procedures is used to identify determinants of number of goats supplied to the market and it includes those variables used in Heckman first step procedure except one or more exclusion restriction variables. This study used lagged price as selection variable in participation equation which was found to affect live goat market participation decision but has no significant effect on number of goat supplied to the market in order to predict inverse of the Mills' ratio correctly. The coefficient of Mills ratio (Lambda) in the Heckman second-step estimation is significant at 5\% probability level. This indicates sample selection bias, which is the existence of some unobservable household characteristics determining probability of participation in live goat market and thereby affecting the total number of live goats brought to the market. The Heckman selection model's overall goodness of fit was indicated by the wald chi2 $(11)=352.11$ which is significant at $1 \%$ level of significance. This shows that the participation level can be explained by the independent variables jointly included in the selection model. Therefore, Heckman two step sample selection model was relevant model for this study. (Table 3)

Among the hypothesized variables, five of them influenced number of goat supplied to the market significantly. Sex of household head, number of goat owned and credit use affected the live goat supplied to market positively and significantly whereas distance to the nearest livestock market and other livestock owned negatively and significantly affected the level of live goat sales.

Sex of household head: As hypothesized this variable influenced the live goat market supply positively and significantly at $1 \%$ level of significance. Holding other explanatory variables constant, as compared to female headed household, male headed household's goat market supply increases by 0.54TLU of goats. The reason behind might be that those households who are female headed household are busy with house work and as well in taking care of their children. This result is in line with Habtamu (2015) who found that being male headed household had positively and significantly affected the level of supply.

Distance to market (dstmkt): This variable influenced number of goat market supplied negatively and significantly at $10 \%$ significance level. Holding other explanatory variables constant, the result shows that as distance away from the nearest livestock market increased by one kilometer, the level of goats supplied to market decreased by $0.06 \mathrm{TLU}$ of goat. This might be due to the fact that the far the market place the higher would be the trekking time, marketing costs, less access to market information and facilities. This is in line with 
Zemeda (2016) who indicated that distance to market caused the quantity of small ruminants supplied to market decrease in Tahtay adyabo district.

Number of goats owned (goatown): As expected, this variable influenced households' number of goats supplied to market positively and significantly at $1 \%$ significance level. As number of goat owned increase by one TLU the number of goat supplied to the market increases by 0.16 TLU. This is mainly due to the fact that pastoralists with more number of goats tend to favor the supply of goat and generate cash from goat sale. This result agrees with the finding of Zekerias (2017) who found that number of cattle owned by pastoralists increase the number of live cattle supplied to market.

Livestock owned other than goats (othrtlu): This variable determined number of goats supplied to market negatively and significantly at $1 \%$ significant level. As other livestock owned increased by one TLU the number of goat supplied to market reduced by $0.07 \mathrm{TLU}$. The intuition behind this might be that those households with more number of livestock other than goat tend to mainly disregard the benefits to be generated from supplying goat to the market. Shambel (2013) also reported the same result.

Table 3: Results from Heckman second-step of determinants of number of live goat supplied

\begin{tabular}{llccc}
\hline Variables & \multicolumn{1}{c}{ Coef. } & Std. Err. & $\mathrm{Z}$ & $\mathrm{P}>\mathrm{Z}$ \\
\hline Age of household head & 0.011 & 0.0100081 & 1.11 & 0.265 \\
Sex of household head & $0.541^{* * *}$ & 0.1926553 & 2.81 & 0.005 \\
Education & 0.019 & 0.0341511 & 0.54 & 0.586 \\
Family size & 0.025 & 0.0400434 & 0.63 & 0.527 \\
Distance to market & $-0.062^{*}$ & 0.0323673 & -1.9 & 0.057 \\
Number of goat owned & $0.155^{* * *}$ & 0.0578158 & 2.68 & 0.007 \\
Other livestock owned & $-0.070^{* * *}$ & 0.0139646 & -5.02 & 0.000 \\
Extension contact frequency & 0.020 & 0.0319894 & 0.62 & 0.537 \\
Credit & $0.410^{* *}$ & 0.1596608 & 2.57 & 0.010 \\
Veterinary service use & 0.077 & 0.146436 & 0.53 & 0.599 \\
Off/non goat income & -0.00003 & 0.0000222 & -1.4 & 0.161 \\
Constant & 0.887 & 0.5903267 & 1.5 & 0.133 \\
mills lambda & $0.498^{* *}$ & 0.2240523 & 2.22 & 0.026 \\
$\quad$ rho & 0.780 & & & \\
$\quad$ sigma & 0.639 & & &
\end{tabular}

Note: $* * *, * *$ and $*$ are statistically significant at $1 \%, 5 \%$ and $10 \%$ significance levels respectively.

Source: Own computation from survey result, 2017

Credit use (credit): This variable affected goat market supply positively and significantly at $1 \%$ significance level. Holding other explanatory variables constant, as compared to credit non-users, the level of goat supplied for those households with credit use increased by $0.41 \mathrm{TLU}$. This suggests that credit use would enhance the financial capacity of the farmer to cover possible marketing costs to supply more goats to market. This is in line with Gebremedhin et al. (2015) who found that credit use increases the number of small ruminants supplied to the market.

Inverse mills ratio (LAMBDA): According to the model output, the inverse Mill's Ratio or selectivity bias correction factor affected the number of goat supplied positively and significantly at 5\% significance level and this result suggests that there appears to be unobserved factors that might affect both probability of households goat market participation decision and number of goat supplied, justifying the suitability of the Heckman two stage model for identifying the determinants of number of goats supplied to market.

\subsection{Live Goats Market Outlets and Factors Affecting Their Choices}

Goat producers in the study area have five major market alternatives to sell their goat. Multivariate probit model was used to analyze the determinants of households decision on market outlet choices as households are more likely chooses different outlets simultaneously. The model estimated jointly for five categorical dependent variables namely; (1) large-scale traders, (2) small-scale traders, (3) cooperatives, (4) collectors and (5) ultimate consumers market outlets. The correlation coefficients of the error terms in MVP model had positive as well as negative signs, indicating that there is interdependency between different market outlets chosen by household heads. The signs of correlation coefficients indicate the complementary and competitive nature of different market outlets. The wald $\operatorname{chi}^{2}(50)=177.68$, prob $>c h i^{2}=0.0000$ is significant at $1 \%$ significance level, this implies that the coefficients are jointly significant and the explanatory power of the factors included in the model is satisfactory. The likelihood ratio test of the null hypothesis of independency between market outlet choice decision 
$($ rho21 $=$ rho31 $=$ rho41 $=$ rho51 $=$ rho32 $=$ rho42 $=$ rho52 $=$ rho43 $=$ rho53 $=$ rho54 $=0$ ) is rejected at $1 \%$ level of significance $\left(\operatorname{chi}^{2}(10)=124.82 * * *\right)$. This indicated that there are significant joint correlations for all estimated coefficients across the equations in the model except for large-scale traders and small-scale traders which is negative and insignificant.

The correlation between outlets as shown in the likelihood ratio test indicated that there are negative and significant interdependency between large-scale traders and cooperatives outlets, large-scale traders and collectors outlets, and large-scale traders and ultimate consumers' outlets. On the other hand small-scale traders' outlet had a positive and significant relationship with cooperatives, collectors and ultimate consumers market outlets, and cooperatives outlet had positive and significant relationships with both collectors and ultimate consumers' outlets. While there were positive and significant interdependency between collectors and ultimate consumers outlets. The model result also shows that the probability that goat producers choose large-scale traders, small-scale traders, cooperatives, collectors and consumers market outlets were 35.36\%, 58.63\%, $57.68 \%, 62.48 \%$ and $34.12 \%$, respectively. The joint probability of choosing all market outlets was $3.04 \%$ and the joint probability of failure to choose all market outlets was $0.05 \%$. The multivariate probit model analysis indicated that out of ten explanatory variables included in the model two variables significantly affected the choice of entire outlets at different magnitude and probability level.

Distance to market (dstmkt): Distance to livestock market negatively and significantly affected large scale traders, small-scale traders and consumers' market outlets choice at 5\%, 5\% and 10\% level of significance respectively. While it is positively and significantly affect cooperatives and collectors outlets at 5\% and $10 \%$ significance level. This result showed that as the distance from the livestock market increases the households tend to sell their goat at farm gate and use outlets other than large and small-scale traders' market outlets. This is due to high trekking and other marketing costs to supply goat to the market. This is coincided with Nuri (2016) who found that increase in distance to the market center would decrease the probability of choosing wholesalers outlet, but increase the likelihood of choosing collectors outlet. The result is again supported by the findings of Addisu (2016) and Bezabih et al. (2015) who reported that distance to the nearest market positively influenced the likelihood of choosing retailer outlet.

Table 4: Multivariate probit estimation results for determinants of goat market outlet choice

\begin{tabular}{|c|c|c|c|c|c|c|c|c|c|c|}
\hline \multirow[t]{2}{*}{ Variables } & \multicolumn{2}{|c|}{ Large-scale traders } & \multicolumn{2}{|c|}{ Small-scale traders } & \multicolumn{2}{|c|}{ Cooperatives } & \multicolumn{2}{|l|}{ Collectors } & \multicolumn{2}{|l|}{ Consumers } \\
\hline & Coef. & $\begin{array}{l}\text { Std. } \\
\text { Err. }\end{array}$ & Coef. & $\begin{array}{l}\text { Std. } \\
\text { Err. }\end{array}$ & Coef. & $\begin{array}{l}\text { Std. } \\
\text { Err. }\end{array}$ & Coef. & $\begin{array}{l}\text { Std. } \\
\text { Err. }\end{array}$ & Coef. & $\begin{array}{l}\text { Std. } \\
\text { Err. }\end{array}$ \\
\hline $\begin{array}{l}\text { Age of } \\
\text { household head }\end{array}$ & 0.083 & 0.031 & -0.051 & 0.022 & $0.016^{* *}$ & 0.028 & $0.023 * * *$ & 0.033 & 0.021 & 0.020 \\
\hline $\begin{array}{l}\text { Sex of } \\
\text { household head }\end{array}$ & 0.095 & 0.608 & 0.076 & 0.452 & 0.218 & 0.223 & 0.207 & 0.119 & -0.176 & 0.473 \\
\hline Education level & 0.159 & 0.149 & -0.056 & 0.084 & -0.081 & 0.102 & -0.195 & 0.125 & 0.129 & 0.082 \\
\hline Family size & $0.182 * *$ & 0.133 & $0.116^{* *}$ & 0.106 & -0.146 & 0.112 & -0.143 & 0.045 & 0.059 & 0.096 \\
\hline $\begin{array}{l}\text { Distance to } \\
\text { market }\end{array}$ & $-0.318 * *$ & 0.109 & $-0.128 * *$ & 0.079 & $0.259 * *$ & 0.118 & $0.121^{*}$ & 0.132 & $-0.107^{*}$ & 0.082 \\
\hline $\begin{array}{l}\text { Number of goat } \\
\text { owned }\end{array}$ & $1.156^{* * *}$ & 0.476 & 0.019 & 0.141 & -0.135 & 0.175 & $-0.382 *$ & 0.227 & $-0.399 * * *$ & 0.146 \\
\hline $\begin{array}{l}\text { Other livestock } \\
\text { owned }\end{array}$ & -0.191 & 0.053 & -0.057 & 0.035 & -0.049 & 0.050 & 0.186 & 0.063 & 0.054 & 0.033 \\
\hline $\begin{array}{l}\text { Extension } \\
\text { contact }\end{array}$ & 0.105 & 0.094 & 0.023 & 0.076 & -0.041 & 0.096 & -0.369 & 0.140 & -0.038 & 0.075 \\
\hline Credit use & 0.238 & 0.469 & -0.281 & 0.423 & 0.523 & 0.482 & -0.152 & 0.159 & 0.240 & 0.401 \\
\hline Selling price & $0.0031 * * *$ & 0.0066 & $0.0013 * *$ & 0.0005 & $-0.002 * *$ & 0.001 & $-0.0022 * * *$ & 0.0008 & $0.002 * * *$ & 0.0005 \\
\hline Constant & $-5.135 * *$ & 2.320 & 1.143 & 1.513 & -0.965 & 1.373 & -1.634 & 1.518 & -3.075 & 1.452 \\
\hline Predicted & 0.353 & & 0.586 & & 0.577 & & 0.624 & & 0.341 & \\
\hline
\end{tabular}

probability

Joint probability (success) $\quad 0.0304$

Joint probability (failure) $\quad 0.0005$

$\begin{array}{ll}\text { Number of draws }(\#)=5 & \text { Number of obs. }=123 \quad \text { Log likelihood }=-294.46\end{array}$

$(-) \operatorname{rho} 31^{*},(-) \operatorname{rho} 41^{* * *},(-) \operatorname{rho} 51^{* *},(+) \operatorname{rho} 32^{* *},(+) \operatorname{rho} 42 * *,(+) \operatorname{rho} 52^{* *},(+) \operatorname{rho} 43 * *,(+)$ rho53***, $(+)$ rho54***

Likelihood ratio test of $\operatorname{rho} 21=\operatorname{rho} 31=\operatorname{rho} 41=\operatorname{rho5} 1=\operatorname{rho} 32=\operatorname{rho} 42=\operatorname{rho} 52=\operatorname{rho} 43=\operatorname{rho53}=\operatorname{rho54}=0 \quad \operatorname{chi} 2(10)=124.82 * * *$

Dependent variable is goat market outlet choice where Y1=Large scale traders, Y2=Small scale traders, $\mathrm{Y} 3=$ Cooperatives, $\mathrm{Y} 4=$ Collectors and $\mathrm{Y} 5=$ Consumers.

Note: $* * *, * *$ and $*$ are statistically significant at $1 \%, 5 \%$ and $10 \%$ significance levels respectively.

Source: Own computation from survey result, 2017

Selling price (price): Selling price of goat positively and significantly affected the large-scale traders, small-scale traders and consumer market outlets choices at 1\%, 5\% and $1 \%$ level of significance respectively. In 
contrary, the variable affected the selection of cooperatives and collectors market outlets negatively and significantly at $5 \%$ and $1 \%$ level of significance respectively. The findings showed that the goat suppliers receive a better selling price from large-scale traders, small-scale traders and consumers as compared to collectors and cooperatives. Therefore households prefer to choose large-scale traders, small-scale traders, and consumer outlets than choosing cooperatives and collector market outlets as they pay less. This finding is related with Melkamu (2016) who reported that selling price significantly and positively affected wholesalers and consumer outlets and negatively affected collector outlet choice. Sultan (2017) found that price offered by market outlets affected cooperative market outlet negatively and significantly.

\section{CONCLUSION AND RECOMMENDATIONS}

\subsection{Conclusion}

Ethiopia is country with the largest small-ruminants population in Africa. This sub-sector plays significant role in improving income and livelihood of large portion of rural households in the district in terms of nutrition, income and intangible benefits (savings, insurance against emergencies, cultural and ceremonial purposes). However, the subsector faces various marketing challenges in the district. The study was aimed at analyzing goat market chain in Moyale district, Borena zone, Oromia region, Ethiopia. The study objectives are: (1) to analyze the determinants of goat market participation decision and level of supply; and (2) to analyze live goats market outlets and factors affecting their choices.

To meet the objectives of the study primary data were collected from 196 goat producers using pre-tested structured questionnaires and secondary data from different district offices, CSA, published and non-published sources. Econometric models (namely; Heckman two stages and multivariate probit model) were used to analyze the data collected from sample goat producer households.

Heckman two stages model was used to identify the determinants of participation decision and level of participations. The result showed that; family size, credit use and lagged price were positively and significantly determined participation decision, while distance to market and other income negatively and significantly determined participation decision. Moreover the result indicated that the number of goat supplied was affected positively and significantly by sex of household head, number of goat owned and credit use. While on the other hand it is negatively and significantly affected by distance to market, other livestock owned and other income.

The Multivariate probit model (MVP) was employed to identify factors affecting the decision of goat suppliers' to choose among alternatives market outlets. The model result showed that distance to livestock market negatively and significantly affected large scale traders, small-scale traders and consumer market outlets choice, while it affected cooperatives and collectors market outlets positively. Selling price of goat positively and significantly affected the small-scale traders', large-scale traders' and ultimate consumers' market outlets choices, while the variable affected cooperatives' and collectors' market outlets choice negatively and significantly.

In general, the study concludes that demographic, socio-economic and institutional factors play a vital role in determining live goat market participation decision, number of goats supplied and producers' market outlet choice decision. However, the general situation of goats' market in the district needs to be improved. Hence, efforts ought to be made to enhance the goat market participation, improve the number and quality of goats supplied to the market as well as market outlet choice decision in the study area.

\subsection{Recommendations}

Depending up on the findings of the study the succeeding recommendations have been made to be considered by responsible bodies in promoting goat marketing in the study area for the betterment of generation to come.

Distance to the nearest livestock market significantly and negatively affected the participation decision and number of goats market supply. Therefore, developing market infrastructure such as building market places, repairing roads and improving road networks to production areas reduce trekking time, minimize transportation and other marketing costs which in turn improve goat market participation and increase goat supply to the market. The development of transport infrastructures also enables households (particularly aged households) to supply their animal to better offering outlet rather than being exploited by nearby collectors for whom distance to market is an asset.

Family size (active labor force) positively and significantly influenced participation of households to the market. The variable again affected the choice of large and small-scale traders' market outlets positively and significantly. It is important for raring and also trekking the animals to the market. Lack of such labor force has a great impact on households' decision to participate and supply their animal to a better offering market outlets. Therefore, improving the capacity of available productive labor of the households is important to increase goat production, market participation and supply to the well-paying market outlets such as large-scale traders.

Credit use by producers positively and significantly affected goat market participation and number of goat supplied. Therefore, increasing and facilitating more financial institutions are critical in helping goat producer 
households' capacity to cover the marketing costs it takes to participate in the market and in turn supply more to the market. Therefore Credit providing institutions need to attract goat producers to the institution by linking them with the main urban and nearby supply of the service providing institutions.

Other livestock holding have negative and significant effect on the number of goat supplied to the market and the other income generated form non-goat business activity was negatively and significantly affected households decision to participate on goat market. This is mainly due to an inadequate recognition of the contributions goats make to the livelihoods of the poor. Therefore, market oriented training focused on awareness creation about the advantage of having alternative income sources and the real benefit to be obtained from goat marketing should be given.

Number of goats owned positively and significantly determines number of goats supplied to the market. Similarly it affected the choice of large-scale traders' market outlet positively and significantly and in contrary, it negatively and significantly affected the choice of collectors and ultimate consumer market outlets. Therefore, the concerned body needs to focus on increasing goat production which could be achieved through providing improved feed and other agricultural technologies. This in turn will enhance the choice of large-scale traders' outlet which buys large number of animal at once.

One year lagged price positively and significantly influenced goat market participation decision of households. High price in the previous production season results in improvement in the goat market participation by goat producer households. Therefore, information about previous year price can improve market participation decision of producer households.

\section{REFERENCE}

Addisu Hailu. 2016. Value Chain Analysis of Vegetables in Ejere District, West Shoa Zone, Oromia National Regional State of Ethiopia. MSc Thesis. Haramaya University, Haramaya, Ethiopia.

Bezabih Emana, Mengistu Ketema, Jemal Yousuf, Jeffreyso, K. 2015. Factors affecting market outlet choice of potato producers in Eastern Hararge Zone. Journal of Economics and Sustainable Development, 6(15): 2222-2855.

Birara Endalew and Zemen Ayalew. 2016. Assessment of the Role of Livestock in Ethiopia: American-Eurasian Journal of Scientific Research, 11 (5): 405-410.

Cappellari, L. and S. Jenkins. 2003. Multivariate probit regression using simulated maximum likelihood. The Stata Journal, 3(3): 278-297.

Charles, B., James, O. and Stephen, O. 2015. Socio-economic Aspects of Goat Production in a Rural Agropastoral System of Uganda: Universal Journal of Agricultural Research, 3(6): 203-210

Cochran, W.G. 1977. Sampling Techniques, 3rd Edition. John Wiley \&Sons, New York.

Central Statistical Agency (CSA). 2017. Agricultural Sample Survey. Volume II: Report on Livestock and Livestock Characteristics (Private peasant holdings). Statistical Bulletin. 585. Addis Ababa, Ethiopia.

Desta Solomon, Berhanu Wassie, Gebru Getachew and Amosha Dadhi. 2008. Pastoral drop out study in selected districts of Borana Zone, Ormoiya Regional State. Care International in Ethiopia.

FAO (Food and Agricultural Organization of the United Nations). 2013. East Africa Cross Border Trade Bulletin. Nairobi, Kenya.

Gebremedhin Berhanu, Hoekstra, D., Tegegne Azage, Shiferaw Kaleb and Bogale Aklilu. 2015. Factors determining household market participation in small ruminant production in the highlands of Ethiopia. LIVES Working Paper 2. Nairobi, Kenya: International Livestock Research Institute.

Gezehagn Gesese. 2015. Beef cattle value chain analysis in Konso District, Southern Nations, Nationalities And Peoples’ Region, Ethiopia. MSc Thesis, Haramaya University, Haramaya, Ethiopia.

Greene, W.H. 2012. Econometric Analysis, $7^{\text {th }}$ Edition. Pearson Prentice Hall, USA.

Habtamu Gebre. 2015. Analysis of potato value chain in Hadiya zone of Ethiopia. MSc Thesis, Haramaya University, Haramaya, Ethiopia.

Jemal Farah. 2017. Analysis of camel milk value chain in Degahbour Woreda, Jarar Zone, Somali Regional State of Ethiopia. MSc Thesis. Haramaya University. Haramaya, Ethiopia.

Legese Getachew, Haile Aynalem, Duncan Alan, Dessie Tadelle, Gizaw Solomon. and Rischkowsky Barbara. 2014. Sheep and goat value chains in Ethiopia: A synthesis of opportunities and constraints. ICARDA/ILRI Project Report, Nairobi, Kenya.

Melkamu Bazie. 2016. Potato value chain analysis in Banja District, Awi Zone of Amhara Region, Ethiopia. MSc Thesis. Haramaya University. Haramaya. Ethiopia.

Moyale District Pastoral Development Office (MDPDO). 2017. Livestock population in Moyale district. Unpublished.

Nuri Lefebo. 2016. Value chain analysis of enset (Ensete ventricosum) in Hadiya Zone, Southern Ethiopia. PhD Dissertation, Haramaya University, Haramaya, Ethiopia.

Shambel Bekele. 2013. Analysis of cattle value chain in Wolaita zone of SNNPRS, Ethiopia. MSc Thesis, 
Haramaya University, Haramaya, Ethiopia.

Solomon Abegaz, Mwai, O., Grum Gebreyesus, Aynalem Haile, Rischkowsky, B.A., Solomon Gizaw and Tadelle Dessie. 2014. Review of goat research and development projects in Ethiopia. ILRI Project Report. Nairobi, Kenya: International Livestock Research Institute.

Sultan Usman, Jema Haji and Eluid B. 2017. Factors Affecting Market Outlet Choice for Wheatin Sinana District, Bale zone, Ethiopia. Journal of Economics and Sustainable Development, 8(17): 2222-2855.

Weldeyesus Gebreyowhens and Kumar, R. 2018. Management and breeding objectives of Maefur goat breed type in Erob district, Eastern zone of Tigray, Northern Ethiopia: International Journal of Livestock Production, 9(3): 50-66.

Zekarias Bassa. 2017. Market chain analysis of live cattle in Borana pastoral area: The case of Moyale district, Oromia Regional State, Southern Ethiopia. Hawassa University Wondogenet College of Forestry and Natural Resource. Juniper publishers.

Zemeda Desta. 2016. Value chain analysis of small ruminant in Tahtay Adyabo district, Tigray, Ethiopia. MSc Thesis, Haramaya University, Haramaya, Ethiopia. 